\begin{tabular}{|l|l|l|}
\hline \multicolumn{2}{|c|}{ PublisherInfo } \\
\hline \hline PublisherName & $:$ & BioMed Central \\
\hline \hline PublisherLocation & $:$ & London \\
\hline \hline PublisherImprintName & $:$ & BioMed Central \\
\hline \hline
\end{tabular}

\title{
Antigen challenge and airway remodeling in mice
}

\begin{tabular}{|l|l|l||}
\hline \multicolumn{2}{|c||}{ ArticleInfo } \\
\hline \hline ArticleID & $:$ & 1620 \\
\hline \hline ArticleDOI & $:$ & $10.1186 /$ rr-2001-68537 \\
\hline \hline ArticleCitationID & $:$ & 68537 \\
\hline \hline ArticleSequenceNumber & $:$ & 31 \\
\hline \hline ArticleCategory & $:$ & Paper Report \\
\hline \hline ArticleFirstPage & $:$ & 1 \\
\hline \hline ArticleLastPage & $:$ & 3 \\
\hline \hline & & RegistrationDate $: 2001-9-18$ \\
ArticleHistory & $:$ & Received \\
& Accepted 2000-12-21 & $:$ 2001-9-18 \\
\hline \hline ArticleCopyright & $:$ & Biomed Central Ltd2001 \\
\hline \hline ArticleGrants & $:$ & \\
\hline \hline ArticleContext & $:$ & 129312211 \\
\hline \hline
\end{tabular}


Kristen Page, ${ }^{\text {Aff1 }}$

Corresponding Affiliation: Aff1

Aff1 The University of Chicago, IL, USA

\section{Keywords}

Airway hyperreactivity, dexamethasone, eosinophils, remodeling

\section{Context}

Chronic inflammation and a significant amount of airway remodeling are commonly seen in asthmatics and are thought to contribute to the severity of the disease. Few studies have attempted to study the effects of lung inflammation in an animal model. In this study, BALB/c mice were sensitized with ovalbumin (OA) and the kinetics of airway inflammation and remodeling processes following OA aerosol challenge were determined. Parameters such as inflammatory cell influx, interleukin (IL)-4, IL-5, and cellular fibronectin levels, plasma leakage, cellular proliferation and mucus secretion were studied. Furthermore, the effect of dexamethasone given prior to OA aerosol challenge was tested.

\section{Significant findings}

Mice were challenged once (acute) or challenged daily for 5 consecutive days (chronic) with OA and were killed at specific time points. Bronchoalveolar lavage fluid (BAL) from both the acute and chronic models contained neutrophils and eosinophils, while lymphocytes were detected only following chronic challenge. Increases in IL-4, IL-5, and cellular fibronectin were detected in the BAL in both models, but were more significant in the chronic model. While total serum IgE levels increased due to the sensitization procedure, repeated challenges induced further increases in IgE levels in the chronic model. Increases in epithelial cell proliferation and mucin secretion were detected in both models although with different time courses. Dexamethasone treatment $1 \mathrm{~h}$ prior to OA challenge fully inhibited the inflammatory parameters, significantly inhibited cell proliferation, and partially inhibited cellular fibronectin content and mucin production. 


\section{Comments}

These investigators have described an allergen-driven murine model of lung inflammation that seems to simulate many of the features of human asthma. While this model cannot give a complete picture of the remodeling processes characteristic of asthma (the chronicity of the disease probably plays a role), it is a useful method to demonstrate many aspects of this disease and the efficacy of potential therapeutic interventions.

\section{Methods}

BAL, ELISA, immunostaining

\section{Additional information}

\section{References}

1. Trifilieff A, El-Hashim A, Bertrand C: Time course of inflammatory and remodeling events in a murine model of asthma: effect of steroid treatment. Am J Physiol Lung Cell Mol Physiol. 2000, 279: L1120-L1128.

This PDF file was created after publication. 